\title{
The Rana Plaza Collapse and the Case for Enforceable Agreements with Apparel Brands
}

\author{
Ben Vanpeperstraete
}

\begin{abstract}
Disasters like the Rana Plaza collapse and the Tazreen Fashions and Ali Enterprises fires painfully demonstrate the limits of conventional models of labour regulation in global supply chains. Buyer-driven markets characterised by outsourcing, subcontracting and offshoring, and the price pressure that results from them, undermines both the regulatory role of the state and the potential for collective bargaining. As a result, poor and unsafe working conditions prevail in transnational corporate supply chains in the garment industry. The aforementioned disasters offer a textbook example of the challenges facing the current clothing industry and the limits of the dominant "Corporate Social Responsibility" (CSR) model used to address labour rights abuses.

Yet, the responses to these disasters also provide fertile ground for alternative "worker-driven" strategies, where worker organisations enter into negotiated supply chain agreements with transnational corporations and hold the latter to account. The Bangladesh Accord and Rana Plaza Arrangement, as well as the corollary Tazreen Compensation Agreement and Ali Enterprises Compensation Agreement attempt to develop a counter-hegemonic alternative to dominant CSR practices and offer new strategies for social justice within global supply chains. This chapter describes and contextualises these agreements in a broader trajectory of labour organisations bargaining and negotiating such agreements with lead firms, highlighting how the post-Rana Plaza momentum made significant strides possible in terms of the depth, scope and enforceability of these negotiated agreements. The chapter identifies the strengths of these developments, but also identifies room for improvement for future negotiated enforceable agreements with apparel brands.
\end{abstract}

Keywords Enforceable Brand Agreements (EBAs) · Private governance - Labour standards · Global supply chains · Apparel · Freedom of association · Corporate social responsibility $\cdot$ Workers' rights $\cdot$ South Asia

B. Vanpeperstraete $(\triangle)$

ECCHR, Berlin, Germany

e-mail: vanpeperstraete@ecchr.eu

(C) The Author(s) 2021

M. Saage-Maaß et al. (eds.), Transnational Legal Activism in Global Value Chains, Interdisciplinary Studies in Human Rights 6,

https://doi.org/10.1007/978-3-030-73835-8_9 


\section{Introduction}

After the 2012 Ali Enterprises fire in Baldia Town (Karachi, Pakistan) killed at least 258 workers, survivors and labour rights groups immediately focused on establishing responsibility and securing financial compensation for the survivors and families of the deceased. ${ }^{1}$ After a struggle comprised of legal action and campaigning — which took the better half of a decade-long-term compensation was finally agreed with the factory's biggest buyer, the German lead firm ${ }^{2} \mathrm{KiK}$. The resulting Ali Enterprises Arrangement borrowed heavily from the previously concluded Rana Plaza Arrangement.

After securing compensation, both Pakistani and global unions as well as other labour rights groups have increasingly turned to advocacy to ensure that similar tragedies are avoided in the future. ${ }^{3}$ Indeed, the problems that led to the Baldia tragedy are endemic to the entire South Asian, and by extension the global, garment industry. Amidst all of the possible policy options for preventing similar tragedies from occurring again, the Bangladesh Accord on Fire and Building Safety represents one example of an instrument designed to achieve such an objective. Recent calls for a similar Pakistan Accord and even calls for an agreement on wages demonstrate the inspiration that the Bangladesh Accord brings to labour rights groups for workerdriven alternatives.

This chapter contextualises the achievements regarding compensation and calls for prevention through negotiated agreements between worker organisations and transnational corporations (lead firms) within a broader trajectory of social movement strategies for improving labour rights in global supply chains. It first provides a succinct overview of the globalised garment industry in South Asia, where mainstream "Corporate Social Responsibility" (CSR) efforts have only minimally addressed the challenges of ensuring labour rights in globalised supply chains. Secondly, it explores direct agreements between worker organisations and lead firms as a distinct counterstrategy to the dominant CSR approach proposed by lead firms. Although based on conventional labour management approaches adapted to a supply chain context, the nascent practice of enforceable supply chain agreements has been taken to the next level with the adoption of the Bangladesh Accord ${ }^{4}$ and the

\footnotetext{
${ }^{1}$ See also chapters by Miriam Saage-Maaß, by Saage-Maaß et al. and by Faisal Siddiqi in this book. ${ }^{2}$ For consistency, the paper uses the term "lead firms" to refer to what is commonly known in the context of the garment industry as brands and retailers, but which can also cover other dominant market parties that do not necessarily have a consumer-focused brand. These transnational companies often design textile, clothing and/or shoes, and market and sell them, while contracting out the actual production. The word brand is used occasionally for stylistic purposes.

${ }^{3}$ IndustriALL, Pakistan's Garment Workers Need a Safety Accord, www.industriall-union.org/ safety-is-our-right-not-a-privilege (last accessed 30 August 2020).

${ }^{4}$ Accord on Fire and Building Safety in Bangladesh, www.bangladesh.wpengine.com/wp-content/ uploads/2018/08/2013-Accord.pdf (last accessed 30 August 2020) and 2018 Accord on Fire and Building Safety in Bangladesh, www.bangladesh.wpengine.com/wp-content/uploads/2018/08/ 2018-Accord.pdf (last accessed 30 August 2020).
} 
conclusion of the Rana Plaza Arrangement. ${ }^{5}$ While the post-Rana Plaza momentum has made significant strides possible in terms of the depth, scope and enforceability of these negotiated agreements, increasing their potential for future application in similar set-ups, advocates have not yet managed to successfully replicate the strategy elsewhere, despite calls from, for example, Pakistan.

\section{The Contemporary Garment Industry Worldwide and in South Asia}

\subsection{The Globalised Garment Industry and Buyer Pressure}

The rapid globalisation of the 1980s created a new context for apparel and footwear brands. Facilitated by cheaper, more efficient and faster transportation and communication, as well as the removal of trade barriers, lead firms who previously owned and managed (most of) their own production capacity, began shifting production to contractors based in low-income countries with weaker labour standards, limited collective bargaining coverage, and poor enforcement. Today, apparel production often takes place in independent factories located in regions of the world where labour costs are lower and social and environmental regulations less stringent. Manufacturing has become characterised by complex, multi-tiered and opaque supply chains often stretching across several countries. As lead firms search for ever-lower production costs, producing countries compete against each other to attract orders. As supply chains have internationalised, the so called "race to the bottom" began.

The emergence of "fast fashion" in the last two decades has meant that lead firms introduce new fashion lines and collections much more frequently and, hence, require quicker inventory renewal. Consequently, lead times for orders to suppliers are no longer planned in months, but rather in weeks. This sourcing model characterised by short lead times on orders frequently results in last-minute changes to product designs and specifications, causing rushes to meet product launches or replenishment. Garment suppliers work on ever-thinner margins and are often forced to sell products to buyers at a price below the production cost. According to an International Labour Organization study into the textile, clothing, leather, and footwear sector, at least $81 \%$ of suppliers have sold goods at below cost price, primarily to secure future orders. When statutory minimum wages have increased in production countries, only $25 \%$ of buyers were willing to increase payments to

\footnotetext{
${ }^{5}$ Rana Plaza Arrangement, Understanding for a Practical Arrangement on Payments to the Victims of the Rana Plaza Accident and their Families and Dependents for their Losses (as amended 20 November 2013), www.ranaplaza-arrangement.org/MOU_Practical_Arrangement_FINALRanaPlaza-c34d165e591e40d43a603e95ac2b38e9.pdf (last accessed 30 August 2020).
} 
suppliers to cover the increased production cost, and those who did made suppliers wait an average of 12 weeks before doing so. ${ }^{6}$

When studying the hyper-competitive structure of global apparel supply chains, Mark Anner concluded that the garment sector is characterised by a buyer-driven sourcing squeeze that has pushed prices down, shortened lead times, and contributed to low wages, health and safety concerns, and violations of freedom of association rights. ${ }^{7}$ In an effort to attract business, investments and trade, both factories and governments of producing countries are disincentivised to protect or respect workers' rights. In turn, working conditions, including wages and working hours, are put further under pressure. $^{8}$ Indeed, the pressure exerted by lead firms has a direct negative impact on textile and cut-and-sew workers, in terms of suppressed wages, ${ }^{9}$ poor health and safety conditions, irregular working hours and excessive and mandatory overtime, unrealistic performance targets and quotas, precarious employment and the lack of stable, permanent work, and (sexual) harassment and abuse by management and supervisors. ${ }^{10}$ Even after the tragic Rana Plaza building collapse in 2013 and commensurate pledges to improve practices, the prices paid by lead firms to suppliers declined by $13 \%$ in the following years. Similarly, lead times shrunk by $8.14 \%$, which increased pressure on suppliers and work intensity for workers, leading to forced overtime, diminished working conditions, and a drop in real wages of $6.47 \%$ (since the December 2013 wage increase) (Fig. 1). ${ }^{11}$

\subsection{The Garment Industry in Bangladesh and Pakistan}

In Pakistan and Bangladesh, the textile and garment industry is of vital importance for the national economy. Indeed, a significant share of both countries' industrial labour force, export earnings, and total gross domestic product are dependent on garment and textile exports. The European Union and the United States of America

\footnotetext{
${ }^{6}$ ILO, Purchasing Practices and Working Conditions in Global Supply Chains: Global Survey Results, 2016, www.ilo.org/wcmsp5/groups/public/\%2D\%2D-ed_protect/\%2D\%2D-protrav/\%2D \%2D-travail/documents/publication/wcms_556336.pdf (last accessed 30 August 2020).

${ }^{7}$ Anner (2018).

${ }^{8}$ Anner et al. (2012).

${ }^{9}$ ILO, Wages and Working Hours in the Textiles, Clothing, Leather and Footwear Industries, 2014, www.ilo.org/wcmsp5/groups/public/@ed_dialogue/@sector/documents/publication/wcms_ 300463.pdf (last accessed 30 August 2020); Cowgill and Huynh (2016).

${ }^{10} \mathrm{ILO}$, Purchasing practices and working conditions in global supply chains: Global survey results, 2017, www.ilo.org/wcmsp5/groups/public/\%2D\%2D-ed_protect/\%2D\%2D-protrav/\%2D\%2D-tra vail/documents/publication/wcms_556336.pdf (last accessed 30 August 2020); Human Rights Watch, "Paying for a Bus Ticket and Expecting to Fly": How Apparel Brand Purchasing Practices Drive Labour Abuses, 2019, www.hrw.org/report/2019/04/23/paying-bus-ticket-and-expecting-fly/ how-apparel-brand-purchasing-practices-drive (last accessed 30 August 2020).

${ }^{11}$ Anner (2018).
} 


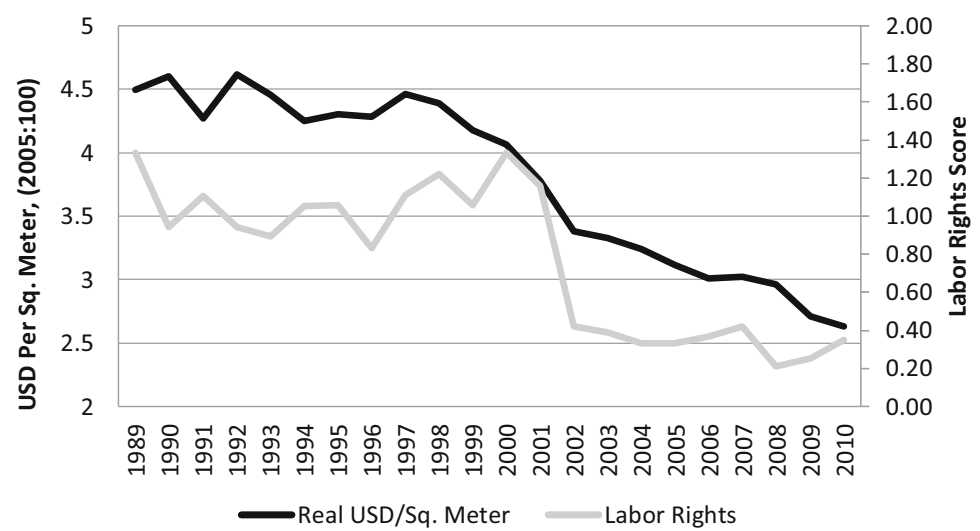

Fig. 1 Labour rights and price per square metre (Source: Anner et al. 2013)

are major export markets for both countries. Bangladesh and Pakistan are the third and fifth biggest garment exporters, respectively, into the EU's single market. ${ }^{12}$ Both countries attract foreign buyers in this labour-intensive sector through a strategy of low labour costs, where export growth is coupled with stagnant wages. ${ }^{13}$ As a result, regulatory functions for labour have become limited or even non-existent, trade union rights are often violated, and employers strongly resist the unionisation of their employees by resorting to intimidation, dismissal, and blacklisting. Furthermore, workers face unhealthy and hazardous working conditions, often without appropriate protective equipment. ${ }^{14}$

The rapid expansion of these domestic industries in Pakistan and Bangladesh has led to a repurposing of many buildings into factories, often without the required permits. Previously existing factories, meanwhile, have often added extra floors or increased the workforce and machinery to levels beyond the safe capacity of their buildings. Many factories run day and night to meet production targets, under the relentless buyer pressure described above. The establishment of new factories and

\footnotetext{
${ }^{12}$ See European Commission, Mid-Term Evaluation of the EU's Generalised Scheme of Preferences (GSP), 2018, www.trade.ec.europa.eu/doclib/docs/2018/october/tradoc_157434.pdf (last accessed 30 August 2020); ILO, Decent work country profile: Bangladesh, 2013, www.ilo.org/ wcmsp5/groups/public/\%2D\%2D-dgreports/\%2D\%2D-integration/documents/publication/wcms 216901.pdf (last accessed 30 August 2020); ILO, Decent work country profile: Pakistan, 2014, www.ilo.org/wcmsp5/groups/public/\%2D\%2D-asia/\%2D\%2D-ro-bangkok/\%2D\%2D-ilo-islama bad/documents/publication/wcms_316668.pdf (last accessed 30 August 2020).

${ }^{13}$ ILO, Wages and productivity in garment sector in Asia and the Pacific and the Arab State, 2016, www.ilo.org/wcmsp5/groups/public/\%2D\%2D-asia/\%2D\%2D-ro-bangkok/documents/publica tion/wcms_534289.pdf (last accessed 30 August 2020); ILO (2014), Cowgill and Huynh (2016).

${ }^{14}$ International Trade Union Confederation, ITUC Global Rights Index, 2020, www.ituc-csi.org/ IMG/pdf/ituc_globalrightsindex_2020_en.pdf (last accessed 30 August 2020); International Trade Union Confederation et al., Bangladesh: Complaint to the European Ombudsman, 2018, www.ituccsi.org/bangladesh-complaint-to-the?lang=en (last accessed 30 August 2020).
} 
conversion of existing buildings into garment factories has often been done as quickly and as cheaply as possible, resulting in widespread safety problems including faulty electrical circuits, unstable buildings, inadequate escape routes, and unsafe equipment. Old and outdated wiring often short-circuits, leading to fire outbreaks, while fire extinguishing facilities, if available at all, are often outdated too.

The price and delivery pressure generated by lead firms in the global apparel industry is not unique to Bangladesh, Pakistan, or even South Asia. Instead, it is a problem facing the global apparel industry. However, it manifests itself in a particularly destructive fashion in Bangladesh and Pakistan, namely in the form of fire and building safety incidents. Indeed, the three most lethal incidents in the globalised garment industry have taken place in Bangladesh and Pakistan, namely the Ali Enterprises fire, the Tazreen Fashions fire, and the Rana Plaza building collapse. ${ }^{15}$

\subsection{South Asia as a Hotspot Demonstrating the Limits of the CSR Industry}

In response to continued disclosures and attention in the public domain by campaigners, NGOs and journalists, lead firms have developed a range of high-profile workplace codes of conduct and industry-driven social responsibility and compliance initiatives. Publicly committing to such codes and their corollary compliance has become a key strategy for lead firms to demonstrate to their customers their commitment and efforts to address labour rights in their supply chains. Yet, this CSR system is either unilaterally defined by lead firms and retailers themselves, or jointly developed in industry-dominated initiatives. To verify risks and track impacts, a severely criticised auditing, certification and CSR compliance industry has also emerged. $^{16}$

\footnotetext{
${ }^{15}$ See also chapter by Palvasha Shahab in this book, which critically discusses the development, implementation, and enforcement of occupational health and safety (OHS) standards in countries like Pakistan. The author explains in detail why there is little difference in fire and building standards worldwide, as well as the poor capacity for government regulatory enforcement in key production countries. This chapter, however, focusses more on the role and ways to effectively implicate lead firms in OHS. The case of the Bangladesh Accord, which is later discussed, and its focus on fire and building safety, partially challenges classical OHS paradigms themselves, as well as the governance of OHS, as fire and building safety is perceived as a core regulatory role of the state. Nevertheless, as we will see later, the Bangladesh Accord does provide potential solutions on how to finance necessary remediations in a transnational context.

${ }^{16}$ See, for example, Pruett D et al., Looking for a quick fix: How weak social auditing is keeping workers in sweatshops, Clean Clothes Campaign, 2015, www.cleanclothes.org/file-repository/ resources-publications-05-quick-fix.pdf/view (last accessed 30 August 2020); Kelly I et al., Fig Leaf for Fashion. How social auditing protects brands and fails workers, Clean Clothes Campaign, 2019, www.cleanclothes.org/file-repository/figleaf-for-fashion.pdf/view (last accessed 30 August 2020); MSI Integrity, Not Fit-for-Purpose: The Grand Experiment of Multi-Stakeholder Initiatives in Corporate Accountability, Human Rights and Global Governance, 2020, www.msi-integrity.org/
} 
Most, if not all, CSR initiatives to date have entirely failed to address poor working conditions in supply chains. At most, they have presented marginal gains that mitigate or render less visible those abuses customers consider to be the most morally repulsive, such as child labour. Especially against the background of continued fire and building safety issues in South Asia it seems clear that the CSR strategies developed and implemented by lead firms have proven to be largely ineffective in addressing the pressures that these same lead firms exert upon their suppliers, which in turn lead to heightened labour and human rights risks and violations. Indeed, the factory collapses and fires across South Asia during 2012 and 2013, preceded by dozens of smaller harmful and deadly incidents for over a decade, combined with an overall lack of demonstrated impact, show the limits of the CSR industry.

All of the factories where major disasters have occurred had been previously and repeatedly audited under prevailing industry audit regimes. ${ }^{17}$ Notably, the track record of so-called "third-party" auditing systems is hardly any better than auditing schemes run by lead firms themselves. The Ali Enterprises factory, for example, had received an SA-8000 certificate from RINA, a Social Accountability International (SAI)-accredited auditing firm, only weeks before its lethal fire in September 2012. The factory had also been audited by Worldwide Responsible Accredited Production (WRAP). ${ }^{18}$ Two months later, 112 workers died in a fire at Tazreen Fashions in Ashulia, Bangladesh, in a factory that had been audited multiple times by Walmart and by UL Responsible Sourcing. Audits of two factories in the Rana Plaza building in Savar, Bangladesh, one performed by Bureau Veritas for the lead firm Loblaw ${ }^{19}$ and another one carried out against the Business Social Compliance Initiative

wp-content/uploads/2020/07/MSI_Not_Fit_For_Purpose_FORWEBSITE.FINAL_.pdf （last accessed 30 August 2020).

${ }^{17}$ For example, the Rana Plaza building passed audits by BSCI and individual lead firms before a collapse killed over 1000 workers. Also, the Hameem/That's It Sportswear factory (29 dead) was directly audited by name brands such as Gap, Abercrombie and Fitch, and Vanity Fair Corporation. The Gharib \& Gharib factory ( 21 dead) was, in turn, audited by H\&M. For a more comprehensive overview of the role of auditing, see the previous footnote.

${ }^{18}$ ECCHR, Case Report: RINA certifies safety before factory fire in Pakistan, 2018, www.ecchr.eu/ fileadmin/Fallbeschreibungen/CaseReport_KiK_RINA_20181121.pdf (last accessed 30 August 2020); Worker Driven Social Responsibility Network, SA8000: The 'Gold Standard' for Failing Workers?, www.wsr-network.org/resource/sa8000-the-gold-standard-for-failing-workers/ (last accessed 30 August 2020); Walsh D and Greenhouse S, Inspectors Certified Pakistani Factory as Safe Before Disaster. The New York Times, 19 September 2012, www.nytimes.com/2012/09/20/ world/asia/pakistan-factory-passed-inspection-before-fire.html (last accessed 30 August 2020); Walsh D and Greenhouse S, Certified Safe, a Factory in Karachi Still Quickly Burned. The New York Times, 7 December 2012, www.nytimes.com/2012/12/08/world/asia/pakistan-factoryfire-shows-flaws-in-monitoring.html (last accessed 30 August 2020).

${ }^{19}$ See Das v. George Weston Limited, 2017 ONSC 4129; Das v. George Weston Limited, 2018 ONCA 1053; Doorey D, Rana Plaza, Loblaw, and the disconnect between legal formality and corporate social responsibility, 2018, www.ssrn.com/abstract $=3265826$ (last accessed 30 August 2020). 
(BSCI) code of conduct, failed to identify the illegal construction and building flaws that led to the plaza's collapse and the loss of at least 1134 lives.

Despite the disappointing results on the ground, the CSR industry has helped erode the idea initially proffered by lead firms in the garment industry that transnational corporations bear no responsibility for human and labour rights abuses in their supply chains. Initially, lead firms viewed their relationship with their suppliers as one between independent partners, each of whom had freely entered into a business agreement, in which the wellbeing of workers was the sole responsibility of suppliers. By developing codes of conduct and compliance regimes to curb the mounting pressure by civil society groups, and by subjecting their suppliers to social audits, lead firms have gradually implied that they do bear some responsibility for labour and human rights conditions in their supply chains after all. More recently, this view has been captured in key soft law instruments like the 2011 UN Guiding Principles on Business and Human Rights (UNGPs) and the updated 2012 version of the OECD Guidelines on Multinational Enterprises. Both normative instruments express a clear global consensus that businesses have a responsibility to respect human rights, including in their supply chains.

\section{Negotiated Brand Agreements}

In response to the emergence of the corporate responsibility to respect human rights as the new global standard of expected conduct for businesses and the disappointing results of prevailing CSR and social compliance regimes, advocates have begun calling for greater accountability through legislative frameworks. ${ }^{20}$ Proponents of a so-called "smart-mix" see more potential for holding corporations to account for human rights abuses by combining a public regulatory route with private "CSRstyle" regulation. ${ }^{21}$ While this rightfully brings up associations with the same voluntary regimes developed by lead firms, the field of private regulation may be providing greater means of accountability than perhaps intuitively imagined. Indeed, while private regulatory approaches are diverse and have often produced disappointing outcomes in the past, equally private approaches in which worker organisations enter into enforceable agreements with lead firms deserve further attention and visibility.

\footnotetext{
${ }^{20}$ See, for example, Business and Human Rights Resource Centre, Call for EU human rights and environmental due diligence legislation now supported by over 100 NGOs, trade unions and networks, www.business-humanrights.org/en/latest-news/call-for-eu-human-rights-and-environ mental-due-diligence-legislation-now-supported-by-over-100-ngos-trade-unions-and-networks/ (last accessed 30 August 2020).

${ }^{21}$ Locke (2013).
} 
Notably, the garment sector has been one of several sectors ${ }^{22}$ in which certain lead firms' concrete supply chain responsibilities have been defined through bargaining structures involving lead firms and worker organisations, usually global unions, national unions, and/or worker-advocacy NGOs. ${ }^{23}$ These agreements have so far sought to regulate and protect (a section of) labour rights in workplaces where the lead firms are not the direct employers of the workers. ${ }^{24}$ Although private contracts in nature, these agreements enable workers and their representatives to hold lead firms accountable for specific commitments in relation to their supply chains. As rights and obligations are developed through bargaining, worker organisations become partners in a decision-making process, as opposed to passive subjects in a unilaterally defined CSR strategy. This has implications for the framing of specific rights and the ways in which they are implemented and eventually enforced, leading to outcomes that are significantly different to those achieved (or not) when workers and their representatives are mere passive entities within lead firms' individual CSR strategies or lead-firm-dominated monitoring initiatives.

Anner et al. chart the development of this strategy in the garment sector back to early twentieth-century multi-party bargaining agreements, in which lead firms agreed to only contract with suppliers that had entered into an agreement with the union. These so-called "jobbers agreements" were negotiated by the International Ladies Garment Workers Union (ILGWU) with the predecessors of today's apparel brands in New York during the mid-twentieth century, when clothing supply chains still had a domestic character. ${ }^{25}$ Yet, this strategy of pursuing contractual agreements

\footnotetext{
${ }^{22}$ Similarly negotiated supply chain agreements have been concluded between labour organisations and lead brands in other sectors, such as the Fair Food Program agreement concluded between the Coalition of Immokalee Workers (CIW) and food retailers and farmers in Florida, and the Milk With Dignity agreement concluded between the group Migrant Justice and dairy product retailers and farmers in Vermont and New York.

${ }^{23}$ These organisations can be quite diverse and include regional and local unions who represent workers at specific production sites, and local NGOs mandated to act on behalf of workers in the absence of democratic and independent union representation.

${ }^{24}$ Given its focus on enforceable agreements between brands and workers' organisations, this chapter does not explore in depth other forms of instruments in which lead firms, retailers and/or labour meet, such as Global Framework Agreements, Responsible Business Initiatives or MultiStakeholder Initiatives. Although a number of these instruments do not enjoy a similar level of enforceability, some GFAs and MSIs do demonstrate modest mechanisms to enforce commitments upon lead firms, sometimes to a greater extent than the instruments discussed here. These other "top down" instruments target one (in the case of GFAs) or several (in the case of MSIs) lead firms with comprehensive regulatory action beyond any single workplace. The agreements covered in this chapter, in contrast, focus on specific topics such as union rights, collective bargaining, factory safety, and compensation. In that sense, they are much more limited in scope, as they do not include other (relevant) labour rights risks, such as poverty wages, overtime, or discrimination. While other instruments focus on a sector-wide approach, the agreements covered here are tailored to specific conditions in a country or to a specific factory incident, and are thus contextualised in local and national circumstances, including laws, norms, practices, the strength of the labour movement, and so on. See, however, Eva Kocher's chapter in this book.

${ }^{25}$ Anner et al. (2013). See also Blasi and Bair (2019).
} 
between labour organisations and brand(s) on one or several issues in a supply chain is equally applicable in the contemporary globalised garment sector. Indeed, in reaction to specific labour rights abuses at factories in the last decades, local trade unions, aided by international allies, ${ }^{26}$ have at times successfully compelled lead firms to take regulatory action and implement concrete commitments in their supplier factories.

Past successes in using such private negotiated approaches have included the reinstatement of workers who had faced retaliatory action from factory management for forming or joining a union of their own choosing. ${ }^{27}$ However, some of these past wins have been precarious or short-lived, with worker reinstatements quickly overturned when international attention waned. ${ }^{28}$ In a few other cases, resolution has managed to go beyond rehiring to include longer-term union recognition and guarantees. $^{29}$ Similarly, local unions together with their allies have sometimes managed to go beyond associational issues to address the non-payment of wages

\footnotetext{
${ }^{26}$ The Clean Clothes Campaign network, through its urgent appeal system, has a track record of campaigning to achieve remedy in specific instances of human rights violations in garment supply chains. See, for example, Den Hond et al. (2014).

${ }^{27}$ IndustriALL Global Union, ITGLWF Commends Goldfame Job Recalls in Cambodia, www. industriall-union.org/archive/icem/itglwf-commends-goldfame-job-recalls-in-cambodia (last accessed 30 August 2020).

${ }^{28}$ See, for example, the River Rich and SL Garment cases in Cambodia, or the Azeem case in Bangladesh. Gregoratti and Miller (2011); Teehan S and Kunthear M, Jubiliation as SL Strike Ends. Phnom Penh Post, 4 December 2013, www.phnompenhpost.com/national/jubilation-sl-strike-ends (last accessed 30 August 2020); IndustriALL Global Union, Cambodian Union Scores Victory at SL Garment, www.industriall-union.org/cambodian-union-scores-victory-at-sl-garment (last accessed 30 August 2020); Odom S, Unions, Bosses Ink Deal to End SL Garment Factory Dispute. The Cambodia Daily, 20 November 2014, www.cambodiadaily.com/archives/unions-bosses-inkdeal-to-end-sl-garment-factory-dispute-72685 (last accessed 30 August 2020); Greenhouse S, Union Leaders Attacked at Bangladesh Garment Factories, Investigations Show. The New York Times, 23 December 2014, www.nytimes.com/2014/12/23/business/international/attacks-onunion-leaders-at-azim-factories-in-bangladesh-are-documented.html (last accessed 30 August 2020).

${ }^{29}$ See, for example, the SF Leather case in Turkey. Clean Clothes Campaign, Turkish workers win case targeting handbag producer Mulberry, www.cleanclothes.org/news/2015/10/19/turkishworkers-win-case-targeting-handbag-producer-mulberry (last accessed 30 August 2020); Clean Clothes Campaign, IndustriALL campaign contributes to Mulberry supplier agreement but struggle continues, www.industriall-union.org/industriall-campaign-contributes-to-mulberry-supplier-agree ment-but-struggle-continues (last accessed 30 August 2020).
} 
and overtime, ${ }^{30}$ and sometimes even to cover issues at the regional level. ${ }^{31}$ However, most campaigns about union recognition, wages or other issues have only addressed a single or a few factories or production sites and have primarily sought to restore or improve pre-existing rights. Agreements at the factory level have remained almost exclusively between workers and factory management, meaning their enforcement has relied on national legal systems, while the involvement of buyers (for example financially) has often been without a formal agreement and therefore could not rely on legal enforcement options. Instead, public pressure from international campaign networks has often been needed not only to conclude such agreements, but also to ensure their adequate implementation.

As these cases demonstrate, the lack of structural and institutional power of local unions can, at least partially and occasionally, be compensated by their access to global unions and civil society networks, which can help build leverage to successfully implicate lead firms in resolving workplace incidents. ${ }^{32}$ It seems logical, then, that unions and social movements would want to expand on such agreements' depth, duration, coverage, and enforceability. The CGT-Fruit of the Loom Agreement, the Indonesia Freedom of Association Protocol, and the Bangladesh Accord are all efforts to transcend individual factory-level struggles between workers and management. Instead of post hoc or ad hoc interventions in which resolution was finally found after the lead firms sourcing from the relevant facilities intervened, these three agreements have worker organisations enter directly into long-term, pro-active agreements with the relevant lead firms that covered multiple facilities supplying the lead firms and included clear dispute resolution mechanisms. Indeed, these three agreements offer some of the most visible and noteworthy examples of worker organisations entering into contracts with lead firms in order to regulate labour rights in the supply chain. At the same time, these agreements vary significantly, as they operate in different parts of world, cover different thematic issues, and have different institutional arrangements.

\footnotetext{
${ }^{30}$ For example, the Nikomas case in the wake of the Indonesia Freedom of Association protocol which is discussed later. Hodal $\mathrm{K}$, Nike factory to pay $\$ 1 \mathrm{~m}$ to Indonesian workers for overtime. The Guardian, 12 January 2012, www.theguardian.com/world/2012/jan/12/nike-1m-indonesianworkers-overtime (last accessed 30 August 2020); Vaswani K, Nike agrees \$1m overtime payment for Indonesian workers. BBC, 12 January 2012, www.bbc.com/news/business-16522992 (last accessed 30 August 2020); Clean Clothes Campaign, Just pay it: Wage compensation for Indonesian Nike workers, www.cleanclothes.org/news/2012/01/12/just-pay-it-wage-compensation-forindonesian-nike-workers (last accessed 30 August 2020).

${ }^{31}$ Worker Rights Consortium, Remediation of Minimum Wage Violations in Bangalore, 2010, www.workersrights.org/university/memo/120210.html (last accessed 30 August 2020); Worker Rights Consortium, Update on Minimum Wage Violations in Bangalore, 2010, www. workersrights.org/communications-to-affiliates/update-on-minimum-wage-violations-in-banga lore-india/ (last accessed 30 August 2020); Clean Clothes Campaign, Factory Tries to Dodge Inflation Correction, www.cleanclothes.org/ua/2013/cases/gokaldas (last accessed 30 August 2020).

${ }^{32}$ See Nasir Mansoor's part in the chapter by Miriam Saage-Maaß et al. in this book.
} 


\subsection{CGT-Fruit of the Loom Agreement (Honduras)}

In response to a worker complaint about the closure of the Jerzees de Honduras (JDH) factory that produced garments for the Russell Athletic brand (owned by Fruit of the Loom), the Worker Rights Consortium asserted that the closure was motivated by union hostility and was, in fact, retaliatory. In 2009, following a successful crossborder campaign led by United Students Against Sweatshops (USAS), ${ }^{33}$ Fruit of the Loom reached an agreement with the Central General de Trabajadores (CGT) of Honduras and its local affiliate, the Sitrajerzeesh union, in which it committed to open a new factory in the Choloma area, rehire the former JDH factory workers, recognise the union and engage in collective bargaining. The agreement also foresaw the back-paying of workers' wages for the period of the JDH factory's closure, a significant wage increase for the rehired workers, and a commitment that, going forward, factory management would not retaliate against any worker forming or joining a union. It also foresaw joint trainings between the lead firm (Fruit of the Loom) and the CGT aimed at the factory management to this effect. ${ }^{34}$

The company agreed to extend this agreement and the associational rights contained therein beyond this single factory to all of its factories in Honduras. The parties created a structure and mechanism whereby the employers (Fruit of the Loom's representatives and factory management) and the unions (the local confederation and international union partners) would provide governance and ongoing accountability for the agreement. The resulting "Washington Agreement" is grounded in Honduran law and includes an oversight committee where both sides are represented together with a joint appointee, and a dispute resolution mechanism where disputes that are not resolved between the parties can be taken to arbitration in front of an ombudsman. ${ }^{35}$

Three out of the five factories covered by the "Washington Agreement" have Collective Bargaining Agreements (CBAs) with Fruit of the Loom. While a number of conflicts about implementation arose, including the closure of a factory, the oversight committee has been successful in mediating implementation conflict, and as a result it appears that the arbitration option has not yet been tested. ${ }^{36}$ Although the factories covered in the agreement are subsidiaries owned by Fruit of the Loom and its brand Russell Athletic, the agreement between the union and Fruit of the Loom remains relevant because "insofar as Russell designs and markets its own brands and sits atop a supply chain that includes independent suppliers as well as

\footnotetext{
${ }^{33}$ Arengo et al. (2019b); Anner (2013).

${ }^{34}$ Maquila Solidarity Network, Historic Victory: Jerzees de Honduras workers win break-through agreement, www.en.archive.maquilasolidarity.org/node/908 (last accessed 30 August 2020).

${ }^{35}$ Lance Compa of Cornell University has been named as ombudsperson. He was nominated by the union and agreed to by all parties.

${ }^{36}$ Worker Rights Consortium, WRC Factory Investigation: Jerzees Buena Vista, 2016, www. workersrights.org/investigations/jerzees-buena-vista/ (last accessed 30 August 2020).
} 
owned and operated factories, it is much more like a jobber [brand] than a traditional apparel contractor."37

\subsection{Indonesia Freedom of Association Protocol}

The Indonesia Freedom of Association (FoA) Protocol ${ }^{38}$ was negotiated by an alliance of five Indonesian union federations, six global sportswear brands, and four major Indonesian footwear manufacturers to (partially) redress the power imbalances between supply chain workers and lead firms. The negotiations resulted from pressure generated by the Play Fair campaign, which leveraged the occasion of the 2008 Beijing Olympics to urge sportswear companies to take a series of concrete, measurable actions to improve workers' rights in supply chains, especially around poverty wages, the abuse of short-term contracts, other forms of precarious employment, violations of freedom of association, and factory closures due to industry restructuring. ${ }^{39}$ The Play Fair campaign selected Indonesia as the ideal location to start negotiations for a country-level instrument due to the footprint in Indonesia of the major lead firms targeted by the campaign (Nike, adidas, Puma, New Balance, Asics and Pentland, with adidas functioning as a spokesperson), the presence and relative strength of independent unions and federations there, ${ }^{40}$ as well as the existence of a broader labour movement in the country with experience in crossborder campaigns. In 2011, after two years of negotiations, an agreement was reached that covered workers' associational rights at all direct suppliers (a major concession for the unions) producing merchandise for the signatory sportswear brands in Indonesia.

Substantively, the agreement outlines the rights of workers and their unions in great detail, provides practical guidelines for organising and collective bargaining, and includes provisions for non-retaliation against trade union officers and limits on employer interference with trade union activities. Especially noticeable is the level of detail with which it covers issues like the release of union representatives from work duties, the use of company materials such as rooms, communication tools, company cars and notice boards, as well as collective bargaining, support from union federations, and the deduction of union fees (see Articles 4-7 of the protocol). In this

\footnotetext{
${ }^{37}$ Anner et al. (2013), p. 34.

${ }^{38}$ For a deeper discussion of the Indonesia Freedom of Association Protocol, see chapter by Reingard Zimmer in this book.

${ }^{39}$ See Maquila Solidarity Network, Clearing the Hurdles: Steps to Improving Wages and Working Conditions in the Global Sportswear Industry, 2008, www.ituc-csi.org/IMG/pdf/Clearing_the_ Hurdles.pdf (last accessed 30 August 2020).

${ }^{40}$ The five different Indonesian unions organised themselves under the banner of Play Fair Indonesia. These unions differ in terms of size, political orientation/affiliation, history, and experience in earlier supply chain casework.
} 
regard, the protocol provides much more detail, tangibility and clarity than current Indonesian legislation. $^{41}$

Under Article 6(1) of the protocol, factories and unions must negotiate a collective bargaining agreement within 6 months after signing the protocol. Signatory lead firms, however, have fairly limited obligations, as they are (only) required to supervise and ensure the implementation of the protocol provisions and serve as members of its national Supervision and Dispute Settlement Committee. Moreover, signatory lead firms are only expected to uphold the protocol's articles and provisions at their tier 1 suppliers. If alleged violations of freedom of association cannot be resolved through consensus and deliberations, Article 9(2) of the protocol states that "dispute should be resolved with reference to legal regulations. If a dispute concerning an infringement cannot be resolved via such negotiations, then the matter should be referred to a court of law." Though Article 2 clearly expresses the binding nature of the agreement, stating that the protocol "binds the parties in the matter of upholding the right to freedom of association," no provisions are included on how to proceed in legal terms should the parties decide to settle in court.

In November 2012, the dispute settlement architecture was further clarified and refined through the adoption of the Standard Operating Procedure (SOP) for the FoA Protocol Supervision and Dispute Resolution Committee. The SOP foresees the establishment of (bipartite) Factory Committees on freedom of association, which are to oversee and report on the implementation of the protocol provisions at the factory level, as well as a Tripartite National Committee, which is to include trade unions, manufacturers, and brand representation, empowered to deal with conflicts that cannot be solved at the factory level. Since the signing of the protocol, however, no disputes have ever been visibly brought in front of the internal dispute settlement mechanism. In all cases of conflict over implementation (by a supplier of a brand) to date, parties have found an agreement before bringing it to the dispute committee, based on the relationship and opportunity for increased dialogue that the instrument provides. $^{42}$

In conclusion, the Indonesia FoA Protocol is a unique example of a negotiated brand agreement that covers a substantial part of the Indonesian garment sector. Importantly, and in contrast to classic codes of conduct under prevailing CSR regimes, Indonesian union federations involved in negotiating the protocol had substantial power to define what freedom of association means in factories in Indonesia at the drafting stage. A decade later, these same unions continue to enjoy a substantial level of ownership over the instrument. At the same time, the protocol does not guarantee freedom of association overnight, but rather provides important additional and structural leverage for local unions to further their own

\footnotetext{
${ }^{41}$ Indonesia has ratified the ILO Convention 87 on the Freedom of Association and Protection of the Right to Organise (1948) and ILO Convention 98 on the Right to Organise and Collective Bargaining (1949) with a simple instrument of ratification, thus not providing additional prescription on freedom of association or collective bargaining beyond that prescribed in the ILO conventions, which are designed to apply globally in all contexts.

${ }^{42}$ Gardener (2012) and Connor et al. (2016).
} 
strategies for achieving freedom of association. In this sense, the protocol has helped create an enabling environment in which unions can claim their rights, challenge anti-union discrimination, and in some cases, also obtain progress on issues like minimum wage. ${ }^{43}$ Hurdles remain in the form of legacy unions, rival unions on the factory floor, and limited organisational capacity on the part of the Indonesian federations to support all factory-level unions and/or to enforce the agreement. Limited organisational capacity of the Indonesian federations is also particularly important when it comes to maintaining the protocol versus attempting to expand it beyond tier 1 suppliers or to cover wages and/or short-term contracts, as initially demanded.

Recent sporting events have shown limited enthusiasm to push for better implementation of the Indonesia FoA Protocol, or to expand its remit beyond tier 1 suppliers or to include issues such as wages and/or short-term contracts. ${ }^{44}$ Likewise, there has only been limited public domain activity to push for similar agreements elsewhere. Unlike other instruments such as the Bangladesh Accord, international allies like global unions or labour rights NGOs do not have a defined space or particular role in the (implementation of the) agreement. And yet, the role of these international allies is important to ensure lead firms remain committed to the robust implementation of the protocol, and to possibly extend its scope or establish similar agreements elsewhere. For example, the recent addition of signatories to the Indonesia FoA Protocol was facilitated through the Fair Wear Foundation, a Dutch multi-stakeholder initiative that includes Dutch trade unions and the Clean Clothes Campaign. ${ }^{45}$

\subsection{Bangladesh Accord on Fire and Building Safety}

The 2013 Rana Plaza collapse in Bangladesh remains the deadliest workplace disaster in the globalised garment industry to date. In its aftermath, over 200 lead firms entered into a legally binding agreement with two global trade unions, UNI Global Union and IndustriALL Global Union, along with eight Bangladeshi trade unions ${ }^{46}$

\footnotetext{
${ }^{43}$ Connor et al. (2016).

${ }^{44}$ The initial demands in "clearing the hurdles" focused on freedom of association, precarious employment, factory closures, and living wages. See Maquila Solidarity Network, Clearing the Hurdles: Steps to Improving Wages and Working Conditions in the Global Sportswear Industry, 2008, www.ituc-csi.org/IMG/pdf/Clearing_the_Hurdles.pdf (last accessed 30 August 2020).

${ }^{45}$ Fair Wear Foundation, Fair Wear members sign Indonesian FoA protocol, 2017, www.fairwear. org/stories/fwf-members-sign-indonesian-foa-protocol/ (last accessed 30 August 2020).

${ }^{46}$ Bangladesh Textile and Garments Workers League, Bangladesh Independent Garments Workers Union Federation, Bangladesh Garments, Textile \& Leather Workers Federation, Bangladesh Garment \& Industrial Workers Federation, IndustriALL Bangladesh Council, Bangladesh Revolutionary Garments Workers Federation, National Garments Workers Federation and United Federation of Garments Workers.
} 
and four NGOs that functioned in a witness capacity. ${ }^{47}$ Building on the content of the earlier Memorandum of Understanding on Fire and Building Safety in Bangladesh, ${ }^{48}$ the final agreement— the Bangladesh Accord on Fire and Building Safety—contains not only unprecedented lead firm participation, but also unprecedented commitments and enforceability. Under the original 5-year agreement, lead firm signatories commit "to the goal of a safe and sustainable Bangladeshi Ready-Made Garment ('RMG') industry in which no worker needs to fear fires, building collapses, or other accidents that could be prevented with reasonable health and safety measures."

The implementation of the Accord is governed through a Steering Committee (SC) which provides equal representation to the signatory lead firms and unions. An ILO representative acts as the SC's neutral and independent chair. The body decides by consensus or through majority votes. Its responsibilities include determining the Accord's budget and financial reporting, appointing the programme's Safety Inspector and Training Coordinator, and managing the dispute resolution process. More concretely, brand signatories agree to finance ${ }^{50}$ and implement a collective fire and building safety inspection programme. All facilities producing goods for signatory lead firms (as opposed to facilities that are only directly contracted by the lead firms) are therefore required to allow independent inspections under the direction of the Accord's Chief Safety Inspector. Inspections are comprehensive and include the structural integrity of buildings, the presence and accessibility of emergency exits, stairwell access, and electrical safety, among other details. The inspections done under the Accord are conducted by qualified engineers who are employed or contracted by the Accord as opposed to individual lead firms or social audit companies. ${ }^{51}$ If the Chief Safety Inspector determines that a specific building presents a "severe and imminent" danger to worker safety, the factory management, its health and safety committee, worker representatives, the SC, and the union's signatory to the agreement are all immediately informed. If a factory faces (partial) closure for remedial work, the signatories are required to keep the workers and pay their regular wages for a maximum of 6 months.

\footnotetext{
${ }^{47}$ Clean Clothes Campaign, Workers Rights Consortium, Maquila Solidarity Network and International Labor Rights Forum.

${ }^{48}$ First discussions on the Memorandum of Understanding started after the 2010 That's It Sportswear fire. By 2012, Tchibo Gmbh and PvH had signed up to the agreement. For a more detailed account, see Clean Clothes Campaign, Maquila Solidarity Network, The History behind the Bangladesh Fire and Safety Accord, 2013, www.cleanclothes.org/file-repository/resourcesbackground-history-bangladesh-safety-accord (last accessed 30 August 2020).

${ }^{49}$ Preamble, Accord on Fire and Building Safety in Bangladesh, www.bangladesh.wpengine.com/ wp-content/uploads/2018/08/2013-Accord.pdf (last accessed 30 August 2020).

${ }^{50}$ The signatory companies must pay an annual fee based on their annual garment production turnover in Bangladesh. Because the Accord is a 5-year agreement between the unions and companies, a company cannot simply unilaterally decide to terminate its commitment to the Accord.

${ }^{51}$ Individual factory CAPs, www.bangladeshaccord.org/factories (last accessed 30 August 2020), aggregated progress reports can be found on www.bangladeshaccord.org/resources/ progressreports (last accessed 30 August 2020).
} 
The Accord also has a unique level of transparency, especially considering the fact that mainstream social compliance initiatives in the garment sector keep inspection reports private. In contrast to this, Article 11 of the Accord states that the inspection reports will be disclosed to "factory management, the factory's health and safety committee, worker representatives (where one or more unions are present), signatory companies and the SC unions, management and buyers within two weeks, and the public within six weeks." In addition, Article 19(c) requires the release of quarterly aggregate reports "that summarize both aggregated industry compliance data as well as a detailed review of findings, remedial recommendations, and progress on remediation to date for all factories at which inspections have been completed." The Accord also ensures a high level of transparency by publishing all inspection reports (both in English and Bengali, with photos) and corrective action plans online, and publicly tracking progress. All of the 150,000+ safety findings and hazards identified to date, as well as their progress on remediation, are publicly accessible.

Another of the Accord's key components are its provisions directly aimed at empowering workers in factories. Article 16 requires the establishment of "an extensive fire and building safety training program [...] with involvement of trade unions and specialized local experts." The aim of the training programme is to both empower workers and support factory owners to jointly take ownership for making and keeping their factories safe. Furthermore, the Accord mandates the establishment of a credible worker-management health and safety committee, with workermembers chosen by their unions and fellow workers. Finally, Article 13 also ensures the right to refuse dangerous work. The Accord further actively involves workers in the process of guarding their own safety through worker trainings, all-staff meetings during which workers are explained their right to refuse unsafe work, and a safety complaints mechanism that is accessible to workers and has managed to resolve direct threats to worker safety, as reported by workers themselves. ${ }^{52}$

Probably the most notable feature of the Accord, and certainly the feature that has garnered the most attention to date, is the fact that the Accord is a legally binding and thus enforceable contract between the parties to the agreement, namely the lead firms and unions. Indeed, lead firm signatories have far reaching obligations under the agreement, namely, to continue their sourcing in Bangladeshi factories ${ }^{53}$ and to ensure the financial feasibility of factories making any necessary renovations. Article 22 states that "[e]ach signatory company may, at its option, use alternative means to ensure factories have the financial capacity to comply with remediation requirements, including, but not limited to, joint investments, providing loans, accessing donor or government support, through offering business incentives or through

\footnotetext{
${ }^{52}$ Arengo et al. (2019a).

${ }^{53}$ Article 23 states that signatories "are committed to maintaining long-term sourcing relationships with Bangladesh," which requires them to "continue business at order volumes comparable to or greater than those that existed in [2012]" for the duration of the Accord (i.e. 5 years).
} 
paying for renovations directly." According to Anner et al., this feature makes the Accord a "buyer responsibility agreement" that establishes joint liability. ${ }^{54}$ Although Article 22 is a crucial clause-as it speaks directly to the purchasing pressure which is so characteristic of the sector-it does not stipulate how signatory companies should comply with its requirements. As such a novel obligation, it has proved to be challenging to fully implement and monitor. ${ }^{55}$ Alternatively, if a supplier fails to make the necessary renovations, even with financing available, Article 21 requires that participating lead firms cease commercial relations with that supplier.

If company signatories fail to live up to the responsibilities outlined in the Accord, they can be held accountable. Article 5 (and later Article 3 in the 2018 agreement) prescribes that any dispute between the parties shall be presented to the steering committee for resolution, which shall decide the dispute by majority vote within 21 days. The body's decision can be appealed to a "final and binding" arbitration process. Awards resulting from the decision "shall be enforceable in a court of law of the domicile of the signatory against whom enforcement is sought" pursuant to the Convention on the Recognition and Enforcement of Foreign Arbitral Awards, ${ }^{56}$ also known as the New York Convention.

Ben Hensler and Jeremy Blasi note that while

legally enforceable commitments subject to binding arbitration are commonplace in international commercial transactions, the Bangladesh Accord is a major breakthrough because it is the first initiative involving multiple lead firms in which the companies have made detailed, legally enforceable commitments to implement international labor rights protections. $^{57}$

To date, the global union signatories have twice initiated arbitration against brand signatories in 2016-2018 (consolidated in a single proceeding). In both cases, the unions argued that the signatories failed to ensure that remediation occurred within the timeframe required by the Accord, and also failed to negotiate financial terms with the factories that would have allowed them to make the required remediations. In January 2018, a settlement was reached with one of the lead firms for its delay in remediating life-threatening hazards at its suppliers. The settlement included two million US dollars to fix safety hazards like locked gates, structural faults, and lacking fire doors and sprinkler systems in more than 150 factories, as well as

\footnotetext{
${ }^{54}$ Anner et al. (2013).

${ }^{55}$ On the one hand, factories may be reluctant to ask for financial assistance from commercial partners. On the other hand, in case brands and retailers have offered financial assistance, they still have an incentive to minimise contributions so as not to incentivise their supplier base too much. Finally, it is also important to note that outside of enforcement actions, it is difficult to monitor this requirement.

${ }^{56}$ United Nations Convention on the Recognition and Enforcement of Foreign Arbitral Awards, New York, 10 June 1948, U.N.T.S. 330, p. 3.

${ }^{57}$ Hensler and Blasi (2013).
} 
300,000 US dollars for the unions who brought the case, for their "Supply Chain Worker Support Fund." 58 The other case settled for an undisclosed but allegedly considerable sum of money. ${ }^{59}$ However, this also means that no arbitral award was issued and, hence, the full potential of the Accord's arbitration system has still yet to be fully tested.

The enforcement mechanism has arguably worked as an effective incentive for lead firms to take their obligations under the contract seriously. In fact, each step in the enforcement protocol has motivated all company signatories to step up their efforts in requiring and supporting their suppliers to make the necessary renovations, therefore boosting the speed at which safety hazards have been addressed. At the same time, it also needs to be recognised that the timing, costs, procedural complexities, and opacity of the Accord arbitration procedure will still require improvement going forward in the legacy agreement, as well as other who might borrow from this clause. In June 2017, the global union federations of IndustriALL and UNI announced an agreement with lead firms' representatives on the language of a successor Accord on Fire and Building Safety in Bangladesh. The new Accord, which took effect in June 2018 after the original Accord expired, extended the programme for an additional 3 years, adding some improvements for the payment of workers' salaries during required remediation work. ${ }^{60}$ In 2020 , however, after a protracted legal battle, ${ }^{61}$ the functions of the Accord were transferred to a national regulatory body that includes the employer association and the government of Bangladesh next to the lead-firms and unions.

\footnotetext{
${ }^{58}$ IndustriALL, Global unions reach US\$2.3 million Bangladesh Accord settlement with multinational brand, www.industriall-union.org/global-unions-reach-us23-million-bangladesh-accord-set tlement-with-multinational-brand (last accessed 30 August 2020); Rushe D, Unions reach $\$ 2.3 \mathrm{~m}$ settlement on Bangladesh textile factory safety. The Guardian, 22 January 2018, www.theguardian. com/business/2018/jan/22/bandgladesh-textile-factory-safety-unions-settlement (last accessed 30 August 2020). Another case with a separate brand using more than 200 suppliers was settled under the Accord in December 2017. The details of that settlement, including the amount of the settlement, remains under a strict confidentiality agreement. See IndustriALL, Settlement reached with global fashion brand in Bangladesh Accord arbitration, www.industriall-union.org/settlementreached-with-global-fashion-brand-in-bangladesh-accord-arbitration (last accessed 30 August 2020).

${ }^{59}$ Anner (2018).

${ }^{60} 2018$ Accord on Fire and Building Safety in Bangladesh, www.bangladeshaccord.org/wpcontent/uploads/2018-Accord-full-text.pdf (last accessed 30 August 2020).

${ }^{61}$ Business and Human Rights Resource Centre, Bangladesh: Accord to continue operations for 281 working days as transition agreement is reached, www.business-humanrights.org/en/latestnews/bangladesh-accord-to-continue-operations-for-281-working-days-as-transition-agreement-isreached/ (last accessed 30 August 2020).
} 


\subsection{Bargaining with Lead Firms}

The CGT-Fruit of the Loom Agreement, the Indonesia FoA Protocol, and the Bangladesh Accord are all agreements that are the result of bargaining between lead firms and labour organisations. Although three agreements may be too few to distil a robust typology of the "enforceable" or "negotiated brand agreement", certain apparent features distinguish this type of agreement from general codes of conduct, multi-stakeholder initiatives, or global framework agreements. Whereas the latter three would cover a broad palette of labour rights in their scope, the three negotiated brand agreements discussed above each address a specific set of working conditions (e.g. freedom of association, collective bargaining, and fire and building safety) within a certain geography by involving and ascribing specific and sometimes far-reaching obligations to an otherwise distant yet powerful and crucial actor in workplace relations, namely lead firms.

Unlike the CGT-Fruit of the Loom Agreement, both the Indonesia FoA Protocol and the Bangladesh Accord also include multiple lead firms, from a modest number broadly covering the sports apparel sector in Indonesia to over 200 lead firms spanning a vast part of the garment sector in Bangladesh. For a significant number of factories, the extent of such agreements' lead firm coverage in a sector can be important because they supply to multiple lead firms. The fact that a high percentage of a factory's buyer volume is covered by obligations under an agreement with worker organisations is more likely to compel the ownership and management of the factory to improve practices in line with the agreement's requirements. While sometimes this leverage can be achieved by a single brand, in a number of occasions different signatories can pool their leverage. At the same time, and probably even more in contrast to general codes of conduct, compliance initiatives, multistakeholder initiatives, or even global framework agreements, these instruments focus on specific labour rights risks which are adapted and contextualised within a specific geographic context (e.g. Honduras, Indonesia or Bangladesh). This allows these agreements to be sensitive and responsive to the distinct localised settings in which the labour rights are embedded. Unlike more globalised approaches such as MSIs or GFAs, this also allows for much more detailed and targeted interventions.

Many of the human rights risks and violations in the garment industry not only occur in a particular factory but are part of a more general sectoral pattern. For example, the causes of the poor fire and building safety record in Bangladesh cannot be ascribed to an individual factory or lead firm, but are, instead, the logical outcome of a structurally complex garment industry. Yet, while the same purchasing squeeze that leads to many workplace violations is felt throughout the global garment industry, it is specifically in South Asia that this pressure manifests in such widespread fire and building safety issues. Addressing fire and building safety requires a high degree of coordination between actors and tailored incentives for multiple factories, companies, social partners, and government agencies, therefore making it more likely to escape the scope of what is possible within single lead firm initiatives or corporate-dominated initiatives. Perhaps the "meso-level" nature of 
the three negotiated brand agreements discussed strikes the right balance between necessary scale and not losing focus on concrete, tangible and granular interventions at the workplace.

All three agreements also aim to impose (increasingly) specific commitments upon lead firms, demanding behaviour that they would be unlikely to commit to voluntarily. This includes bringing the behaviour of lead firms, including purchasing practices, into the scope of the agreement which stands in contrast to conventional CSR approaches and social compliance initiatives, where the supplier's behaviour is the exclusive focus of intervention. In the set-up of the agreements themselves, there is also a clear aspiration to establish joint management structures and dispute resolution mechanisms with the aim of allowing labour rights organisations to substantially shape and alter outcomes. In this regard, it is important to highlight that all of these agreements resulted from intense campaigning by activists, trade unions and NGOs, as only a few lead firms would ever enter into such an agreement without some form of public or regulatory pressure. This pressure can be achieved through transnational campaigning, as exemplified by the Honduras and Indonesia agreements, or in conjunction with a significant event and subsequent international media attention, like in the case of the Rana Plaza collapse and the Bangladesh Accord. In each of these three cases, campaigners and activists were crucial in challenging lead firms in their consumption markets on issues in their supply chains, and bargaining (or supporting bargaining) to redress spatially stretched power relations.

The Bangladesh Accord stands out from the other two agreements in terms of its legal enforceability, which represents, as Juliane Reinecke and Jimmy Donaghey note, "a very significant new departure in global supply chain labor governance.",62 While unique, it is important to remember that the Accord's capacity for enforcement still remains new, largely uncharted territory; there are no precedents, and so many details remain unclear and untested. For example, the 2013 Accord failed to spell out how the involved parties should select an arbitrator, choose the applicable jurisdiction or law, or what should happen if they could not come to an agreement. This gave rise to procedural delays when the mechanism was activated and led to arbitration under the Accord requiring considerable time, resources and energy, while remaining relatively opaque. ${ }^{63}$ And while the extent of the original arbitration clauses has never been fully tested, it already provided options for how Accord-style arbitration could be further streamlined, as visible in the Accord's 2018 successor agreement. A recent publication also offers model clauses for making such a dispute

\footnotetext{
${ }^{62}$ Reinecke and Donaghey (2015), p. 32.

${ }^{63}$ The Accord proceedings where in contrast to most arbitral proceedings, relatively transparent with only details that could identify the respondents being omitted. For the procedural clarifications needed, see PCA case no. 2016-37 and PCA case no. 2016-37 Procedural Orders 1-8, which took over a year after commencement of the proceedings, www.pca-cpa.org/en/cases/152/ (last accessed 30 August 2020).
} 
settlement more efficient, transparent and cost-conscious in a way that respects the rights and interests of the different parties. ${ }^{64}$

However, even the Bangladesh Accord, which arguably has the most robust enforcement mechanism and therefore the strongest internal dispute mechanism, has needed to rely on additional public and NGO scrutiny for its implementation. The NGO witness signatories to the Accord, who do not have access to its dispute resolution mechanism, have felt compelled to publicly show their concern on several occasions in relation to delays in remediation. One notable example involved the witness NGO signatories shining a spotlight on $\mathrm{H} \& \mathrm{M},{ }^{65}$ in which they publicly observed that "by now, each of these factories [surveyed] should have already completed all required renovations, with minimal exceptions". ${ }^{66}$ By making such a public move, the NGOs successfully pressured H\&M and other lead firms to step up their implementation efforts. They also reminded everyone that these negotiated agreements not only come about through public domain pressure, but that they also require continued external pressure to ensure their robust implementation, despite the existence of monitoring capacities and internal dispute mechanisms.

\section{Supply Chain Compensation Fund Agreements}

While the Rana Plaza collapse was a key event leading to the establishment of the Bangladesh Accord that brought new levels of commitments and enforceability to negotiated brand agreements, a similar impact was also seen on supply chain compensation fund agreements. Following lethal disasters, a significant share of international campaign energy has also focused on the development of ex post facto supply chain compensation fund agreements to provide for the longer-term financial needs of survivors and the families of the deceased. These agreements differ from unilaterally defined contributions offered by lead firms as compensation under their own terms for accidents in their supply chains. Instead, they involve a practice in which worker representatives and lead firms (sometimes together with other stakeholders) reach an agreement over the parameters of the compensation and its implementation.

\footnotetext{
${ }^{64}$ Clean Clothes Campaign et al., Model Arbitration Clauses for the Resolution of Disputes Under Enforceable Brand Agreements, 2020, www.laborrights.org/publications/model-arbitrationclauses-resolution-disputes-under-enforceable-brand-agreements (last accessed 30 August 2020).

${ }^{65}$ Clean Clothes Campaign et al., Evaluation of H\&M Compliance with Safety Action Plans for Strategic Suppliers in Bangladesh, 2016, www.laborrights.org/sites/default/files/publications/H\% 26M_Bangladesh_September2015_English.pdf (last accessed 30 August 2020).

${ }^{66}$ Clean Clothes Campaign et al., Ongoing Safety Delays at H\&M Suppliers in Bangladesh, 2016, www.laborrights.org/sites/default/files/publications/Memo_on_HM_CAPs_1-28-2016.pdf (last accessed 30 August 2020).
} 
The first such fund to be established was proposed following the Spectrum disaster. $^{67}$ In April 2005, the Spectrum Sweater factory collapsed in Savar, Bangladesh, killing at least 64 workers and injuring many others. International labour rights groups such as the Clean Clothes Campaign, the ITGLWF (the predecessor of IndustriALL Global Union), and multiple Bangladeshi unions campaigned for the establishment and implementation of a compensation fund. Although only the factory owner and a handful of lead firms (Inditex, KarstadtQuelle, Scapino, New Wave Group, and Solo Invest) contributed, the Spectrum Relief Fund was the first initiative of this kind to be developed in Bangladesh, where an agreement was eventually reached on compensation, pensions, beneficiaries and administration of the scheme. Final pay-outs were made in September 2011.

The same approach was also later applied to the Hameem case. In 2010, the That's It Sportswear factory (part of the Hameem Group) burned down in Bangladesh, leaving 29 dead and 11 seriously injured. In the wake of the fire, the so-called Hameem formula was established, based on the lessons learned from the Spectrum case. The formula provided lump sum compensation for pain and suffering (BDT 500,000) ${ }^{68}$ and compensation for loss of income (calculated as $50 \%$ of the minimum wage in the garment sector for 25 years with an adjustment for the projected average annual inflation rate). The agreement also offered compensation for injured workers. Perhaps equally important is the fact the Hameem formula also stipulated who should contribute to such a fund, apportioning the financial cost of implementation between lead firms, the factory, the employer association, and the government. Later, a compensation scheme was agreed in the case of the Eurotex and Continental factory disaster along the same lines as the scheme developed in the Hameem case. The Hameem formula was also used as a basis for the Wing Star agreement in Cambodia. ${ }^{69}$

\subsection{Rana Plaza Compensation Agreement (Bangladesh)}

In the wake of the Rana Plaza collapse, the Rana Plaza Arrangement was established to provide compensation for victims of the disaster and their dependents. In November 2013, a framework agreement was reached by all possible stakeholders, namely the Bangladeshi government, the Bangladesh Garment Manufacturers and Exporters Association, IndustriALL Global Union and the IndustriALL Bangladesh

\footnotetext{
${ }^{67}$ See for a detailed account Miller (2012).

${ }^{68}$ This constituted a significant upgrade from the BDT 168,000 provided under the Spectrum mechanism, where an initial BDT 100,000 was paid to the families by the employer shortly after the factory collapse.

${ }^{69}$ Clean Clothes Campaign, Bangladesh formula crosses borders to Cambodia, www.cleanclothes. org/ua/2013/cases/wingstar (last accessed 30 August 2020).
} 
Council, the Clean Clothes Campaign, and the Bangladesh Institute of Labour Studies. The agreement foresaw a single process overseen by a Coordinating Committee comprising the signatories' representatives and chaired by the ILO. Among other steps, the committee was tasked with defining a formula for victim compensation and administering the collection and disbursal of funds. ${ }^{70}$

Departing from the Hameem formula, and benefitting from the expertise of the ILO, the agreement was based on principles outlined in ILO Convention 121 on Employment Injury Benefits (1964). The committee established a compensation formula calculated to ensure payments were sufficient to provide an income for the lifetime of all beneficiaries, taking into account different individuals' needs and circumstances. Persons who lost their earnings as a result of injuries sustained in the disaster or dependents of persons killed or missing were eligible to claim compensation. The Rana Plaza Trust Fund was formally established in January 2014, from which time it began accepting contributions that could be made by anyone, including on an anonymous basis. Claims processing and pay-outs began in instalments shortly thereafter. ${ }^{71}$

After an initial assessment of 40 million US dollars, it was finally determined that 30 million US dollars would be needed to satisfy all expected claims. After the initial establishment of the trust fund and the start of its operations, a number of lead firms, the Bangladeshi government, and other stakeholders provided contributions. However, the sum of contributions did not match the total amount needed to enable full minimum compensation for loss of income under the international norm as contained in ILO Convention 121. In the absence of a concrete plan for reaching the required amount, and without a (judicial) route to enforce the MoU, campaign organisations shifted their focus to using public domain pressure to convince lead firms to pay up in order to achieve the required amount. This lack of enforceability was perhaps most clearly illustrated by Benetton's positioning. Citing a lack of clarity in terms of the apportionment for individual lead firm contributions as the main reason, ${ }^{72}$ Benetton only contributed to the fund in 2015 after extensive pressure, including an online petition by Avaaz that gathered one million signatures. ${ }^{73}$ It was only

\footnotetext{
${ }^{70}$ Understanding for a Practical Arrangement on Payments to the Victims of the Rana Plaza Accident and their Families and Dependents for their Losses (as amended 20 November 2013), www.ranaplaza-arrangement.org/mou/full-text/MOU_Practical_Arrangement_FINAL-RanaPlaza. pdf (last accessed 30 August 2020).

${ }^{71}$ The Rana Plaza Donors Trust Fund, www.ranaplaza-arrangement.org/fund (last accessed 30 August 2020).

72،"[S]ince thus far it has not been possible for the RANA PLAZA TRUST FUND, to set forth such principle for any brand," Benetton: Press note-Benetton Group starts global social commitment program for 2015 and launches second phase of support activities for victims of Rana Plaza, www. benettongroup.com/media-press/press-releases-and-statements/press-note-benetton-group-startsglobal-social-commitment-program-for-2015-and-launches-second-phase-of-support-activitiesfor-victims-of-rana-plaza/ (last accessed 30 August 2020).

${ }^{73}$ Butler S, Benetton agrees to contribute to Rana Plaza compensation fund. The Guardian, 20 February 2015, www.theguardian.com/business/2015/feb/20/benetton-agrees-contribute-ranaplaza-compensation-fund (last accessed 30 August 2020).
} 
later in June 2015, after significant public domain pressure, including by governments, ${ }^{74}$ and following a significant anonymous contribution, that the ILO could announce that the Rana Plaza Trust Fund had met its 30 million US dollars target and thus had gathered the funds required to enable full payments to all victims. ${ }^{75}$ Final disbursements were carried out in the ensuing months.

\subsection{Tazreen Claims Administration Trust (Bangladesh)}

In November 2012, just six months before the Rana Plaza collapse, a massive fire broke out at the Tazreen Fashions factory in Ashulia, Bangladesh, killing 113 workers and injuring nearly 200. Though this disaster occurred before Rana Plaza, negotiations on the Tazreen compensation effort did not conclude until November 2014, when it was finally signed by C\&A, the C\&A Foundation, IndustriALL Global Union, and the Clean Clothes Campaign. Despite initial unilateral compensation measures by $\mathrm{C} \& \mathrm{~A}$ and others, the trust could now equally provide for a single approach. Although the delay in reaching an agreement resulted in significantly delayed compensation for the victims, it also meant that the Tazreen Claims Administration Trust could build and borrow significantly from the gains and expertise of the Rana Plaza Arrangement. ${ }^{76}$ Indeed, it used the same actuarial calculations and software, employed the same executive commissioner, and built on other infrastructure developed for the Rana Plaza Arrangement.

Major contributions of one million US dollars were made by the C\&A Foundation and the Fung Foundation (Li \& Fung had placed orders at Tazreen Fashions on behalf of Sean John's Enyce brand). Smaller contributions were made by KiK, El Corte Ingles, and Walmart, with the latter only contributing 250,000 US dollars. Having achieved full funding, the trust was able to provide compensation to all of the injured workers and dependents of those who had been killed in the fire by July 2016. Recipients included 482 family members of 103 deceased workers and 10 missing workers, and 174 survivors who suffered continuing injuries from the fire. These payments, totalling 2.17 million US dollars, in combination with payments made in the immediate aftermath of the fire by the Bangladeshi government, were sufficient to satisfy the awards for all eligible claimants. An additional 350,000

\footnotetext{
${ }^{74}$ Trade Union Advisory Committee, 7 OECD Government Ministers call on brands to compensate Rana Plaza victims after strong Trade Union and NGO push, members.tuac.org/en/public/e-docs/ 00/00/0E/D8/document_news.phtml (last accessed 30 August 2020).

${ }^{75}$ ILO, Rana Plaza victims' compensation scheme secures funds needed to make final payments, 2015, www.ilo.org/global/about-the-ilo/newsroom/news/WCMS_374239/lang\%2D\%2Den/index. htm (last accessed 30 August 2020); Hoskins T, After two years, the Rana Plaza fund finally reaches its $\$ 30 \mathrm{~m}$ target. The Guardian, 10 June 2015, www.theguardian.com/sustainable-business/2015/ jun/10/rana-plaza-fund-reaches-target-compensate-victims (last accessed 30 August 2020).

${ }^{76}$ About the Tazreen Claims Administration Trust, www.tazreenclaimstrust.org/about (last accessed 30 August 2020).
} 
US dollars was set to be transferred to a separate fund to provide ongoing medical treatment for victims of both the Tazreen Fashions fire and Rana Plaza collapse still suffering injuries. ${ }^{77}$

\subsection{Ali Enterprises Arrangement (Pakistan)}

Preceding both the Rana Plaza collapse and Tazreen Fashions fire, the Ali Enterprises factory burned down on 11 September 2012 in the Baldia Town area of Karachi, Pakistan. Despite numerous documented fire safety failures, the facility received its SA-8000 certification three weeks before the fire, therefore claiming it had fulfilled international standards in areas including health and safety, child labour and minimum wage. ${ }^{78}$ The German retailer KiK was the only acknowledged buyer at the Ali Enterprises factory which produced jeans for KiK's Okay Men brand. A public campaign forced $\mathrm{KiK}$ to agree to discuss compensation with the Pakistan Institute of Labour Education and Research (PILER), a local labour rights group. These discussions resulted in a 2012 agreement in which KiK committed to making an initial contribution to an immediate relief fund. The lead firm also agreed to engage in good faith negotiations to determine long-term compensation, but these negotiations did not result in an agreement.

Despite the fire occurring eight months prior to the 2013 Rana Plaza collapse, it was only in September 2016 that an agreement was finally reached to provide compensation for income lost by victims of the fire. Indeed, despite initial commitments to good faith negotiations, it took intense public campaigning, a heavily publicised court case, ${ }^{79}$ and political pressure for the main buyer, $\mathrm{KiK}$, to sit down at the table and work out an agreement facilitated by the ILO, based on lessons learned in the Rana Plaza and Tazreen compensation models.

Under the agreement, which was signed by the ILO, the lead firm KiK, IndustriALL Global Union, and the Clean Clothes Campaign, KiK agreed to contribute 5.15 million US dollars to fund the compensation scheme, in addition to the one million US dollars it had already paid in emergency funding in December 2012. Pakistan's Sindh Employees' Social Security Institution (SESSI), which also previously contributed funds to employees for loss of income and medical care, would be a central implementing actor for the fund and committed to provide an additional 0.7

\footnotetext{
${ }^{77}$ Landmark compensation arrangement reached on 4th anniversary of deadly Pakistan factory fire, www.cleanclothes.org/news/press-releases/2016/09/10/press-release-on-ali-enterprises (last accessed 30 August 2020).

${ }^{78}$ ECCHR, Case Report: RINA certifies safety before factory fire in Pakistan, 2018, www.ecchr.eu/ fileadmin/Fallbeschreibungen/CaseReport_KiK_RINA_20181121.pdf (last accessed 30 August 2020).

${ }^{79}$ Jabir et al. v. KiK Textilien und Non-Food GmbH (Case No. 7 O 95/15, LG Dortmund). See also Terwindt et al. (2017) and chapters by Miriam Saage-Maaß, Faisal Sidiqqi and Saage-Maaß et al. in this volume.
} 
million US dollars as part of the agreement. These funds, totalling 6.6 million US dollars, were determined to be sufficient to meet the requirements for loss of income and medical care for the fire victims and dependents of the deceased under ILO Convention 121, using a proxy "living wage" proposed by the ILO in the absence of direct records of wage rates. ${ }^{80}$

\subsection{Delivering Compensation with Lead Firms}

The compensation agreements outlined in Sect. 4 of this chapter differ from the other brand negotiated agreements between lead firms and labour organisations discussed in Sect. 3 in their ex post facto nature and their singular focus on one specific form of remedy, namely financial compensation. As in the case of the negotiated brand agreements, the Rana Plaza collapse also elevated the way compensation can be delivered following a deadly factory incident to a new level. Similar to the negotiated brand agreements, the compensation agreements discussed here also resulted from labour organisations and lead firms jointly developing a single process for setting the parameters and, if necessary, building the infrastructure and institutions required to effectively deliver compensation. While there was already an established practice of supply chain compensation fund schemes with the so-called Hameem formula, the scale and scope of the Rana Plaza collapse brought in the expertise and legitimacy of the ILO. This had implications for the use of the Hameem formula by labour advocates or lead firms in their own actuarial methods, as a more sophisticated and legitimate actuarial approach could be found in ILO Convention 121.

In almost every compensation agreement discussed in this section, lead firms had initially tried to provide compensation through a unilaterally defined process. Such a unilateral approach poses problems in terms of rights compatibility, as a discrepancy almost always exists between the kind and amount of compensation the implicated lead firms foresee and the expectations of victims and/or (customary) international rights standards. Both the Tazreen and Rana Plaza cases demonstrate this. Following the fire at Tazreen Fashions, several individual initiatives emerged that tried to provide in-kind services to victims and mobilise donations from apparel companies, local employers, the Bangladesh Garment Manufacturers and Exporters Association (BGMEA), and the Bangladeshi government. Despite the value of these responses, these efforts did not meet an international standard for compensation, such as the customary Hameem formula or the norms enshrined in ILO Convention 121. Indeed, without a coordinated approach, the victims' right to full and fair compensation would remain unfulfilled. Such fulfilment was only made possible when labour

\footnotetext{
${ }^{80} \mathrm{ILO}$, Compensation arrangement agreed for victims of the Ali Enterprise factory fire in Pakistan, 2016, www.ilo.org/global/about-the-ilo/newsroom/news/WCMS_521510/lang\%2D\%2Den/index. htm (last accessed 30 August 2020); Payment on claims from survivors of Tazreen factory fire completed, www.laborrights.org/releases/payment-claims-survivors-tazreen-factory-fire-com pleted (last accessed 30 August 2020).
} 
rights groups and global apparel companies developed a single, coordinated approach to compensation.

A single approach is also necessary from an equity perspective. For example, the Rana Plaza building complex housed five factories. Initially, the Irish fast fashion retailer Primark was quick to react to the tragedy, but only for its approved supplier, the New Wave Bottoms (NWB) factory. It committed to paying long-term compensation to the 581 NWB workers, and nine months' salary to workers and rescue workers regardless of their factory of employment. This generated differentiated compensation for individual workers based on the willingness of lead firms to pay, and the parameters lead firms developed. Indeed, in order to implement its commitment, Primark chose to create its own independent system for calculating and delivering payments to the NWB workers and their family members, de facto creating a separate system of compensation from the other Rana Plaza workers. For these NWB workers, compensation was initially calculated according to the "Bangladesh Scale," which was an approach to disability and vulnerability assessments based on Spanish traffic accident law, ${ }^{81}$ as opposed to ILO Convention 121. In response, the Rana Plaza Arrangement decided to compare and adjust amounts under the Primark approach with those that would be offered under ILO Convention 121.

Also important is the amount of learning and institutional transfers possible between the different compensation agreements. The Rana Plaza Arrangement involved an impressive amount of institution building that ranged from developing actuarial parameters to staff and auditing procedures, and included software writing, counselling strategies, etc. The Tazreen Claims Administration Trust and Ali Enterprises Arrangement clearly benefitted from this work, while also learning from and adapting the model. The Tazreen Trust, for instance, deliberately gave a stronger role to local stakeholders in the implementation of the agreement than that provided under the Rana Plaza Arrangement. The Ali Enterprises Arrangement, in turn, addressed up front the issue of low wages that had preceded the lethal tragedy. Both national Employment Injury Insurance Schemes and ILO Convention 121 are $a$ priori neutral on the issue of poverty wages prevalent in the garment sector, which under ILO Convention 121, become the reference for calculating compensation benefits. The Rana Plaza Arrangement and Tazreen Trust both tried to mitigate this by retroactively adapting the calculation to use increased garment sector wages and to create a minimum "floor" of compensation payments. The Ali Enterprises Arrangement, meanwhile, used a "living wage" as a reference wage for additional payments under the scheme from the very the start.

All in all, these compensation agreements also reveal a fairly fragile relationship between multinational companies, labour organisations, and states as they work to ensure access to remedy. Whereas the Bangladeshi government was a member of the Rana Plaza Arrangement Coordination Committee, the domestic legal protections in Bangladesh are minimal at best. The Ali Enterprises Arrangement, in contrast, had to

\footnotetext{
${ }^{81}$ This methodology was developed by Chavier Chercoles, who was also involved in the development of the Spectrum Relief Fund.
} 
take into account but also benefitted from a legal framework being in place and the presence of an implementing authority in the Pakistani province of Sindh. As such, the Ali Enterprises Arrangement carefully bridged the difference between national and international standards on compensation for loss of income, while also providing an opportunity for a strengthened domestic institution to remain in place. Similar to the bargaining agreements described in Sect. 3 in this chapter, the compensation agreements outlined here may are also clearly be sensitive and adapted to distinct localised parameters embedded in local law, social practices or the specific needs of victims.

\section{Conclusions}

Although the negotiated and enforceable agreements discussed in this chapter are private in nature, worker organisations have managed to successfully use them to contest or at least partially balance indirect and spatially stretched power relations in the globalised garment industry. By entering into such agreements, worker organisations and their allies have been able to establish institutional mechanisms with lead companies that aim to mitigate some of the power asymmetries which characterise globalised value chains and to deliver concrete workplace improvements at a very granular level, adapted to local contexts. At the same time, most of these agreements have been hard fought, not particularly stable, and focused on fundamental rights that should have already been guaranteed in the first place.

The different types of agreements concluded jointly between worker organisations (including workers, unions and NGOs) and lead firms provide an avenue for worker organisations to potentially hold lead firms accountable on specific commitments in relation to their supply chains. Under these agreements, lead firms have specific obligations to compel and incentivise their suppliers toward positive change. These obligations can range from merely encouraging suppliers to providing them with funding or improved commercial terms, or imposing penalties that can even include ceasing the business relationship. These agreements can also include direct lead firm (financial) obligations toward workers, for example, by requiring them to either maintain or compensate for the loss of workers' income.

The crucial point is that the definition, implementation, and monitoring of these commitments is done jointly between worker organisations and lead companies. Most of the agreements discussed in this chapter required the establishment of a governance body to oversee, implement, and/or monitor (parts of) the agreement. In some cases, this required the creation of a joint monitoring committee, tasked with overseeing implementation. In other cases, more significant institution building took place, sometimes including the establishment of new legal entities, the contracting of inspectors, the provision of services, and the developing of specific processes and layers of secondary regulation. While all of the agreements were the result of public domain pressure exerted by broader social movements, they all included internal dispute settlement structures to deal with further issues that might arise under the 
agreement. These joint bodies consisted of representatives of parties to the agreement, sometimes with participation of a neutral party. The CGT-Fruit of the Loom Agreement and the Bangladesh Accord also provided an external recourse for final and binding arbitration, whereas other agreements would require state-based judicial mechanisms or campaigning to achieve final dispute resolution.

In the case of the supply chain compensation fund agreements, funding shortages often gave rise to disputes and division between participating lead firms, as did certain lead firms' refusal to contribute (yet). To achieve the 30 million US dollars required for the Rana Plaza Arrangement, labour rights groups eventually resorted to other mechanisms, such as public campaigning. To a certain extent, all of the agreements, even those with more robust internal dispute settlement mechanisms and final arbitration provisions, relied on some form of additional public domain pressure for their implementation. Even the success of the Bangladesh Accord, which arguably has the most robust enforcement mechanism, was in part due continuous NGO scrutiny. Nevertheless, there are good reasons to reduce reliance on public campaigning and create stronger enforcement within such agreements' architecture. The Rana Plaza and Ali Enterprises Arrangements have shown that the majority of apparel companies are often too slow in making sufficient contributions, which can, in turn, create harmful delays in payments to workers or their families. Yet, some interventions will always require specific concerted action from lead firm signatories in order to be effective. The Bangladesh Accord, for example, managed to eliminate over $90 \%$ of the safety hazards originally identified by the Accord inspectors. These types of targeted and concrete impacts would be impossible to achieve through other corporate responsibility strategies targeting lead companies, such as campaigning or even new legislation.

The Bangladesh Accord and its arbitration mechanisms should therefore be seen as a point of departure from which labour advocates must continue to finetune lessons learned. Although the Accord foresees far-reaching commitments for lead firms, future agreements should ideally contain even clearer obligations and corollary mechanisms for monitoring and enforcing these obligations. Clauses that incentivise suppliers to comply, such as potentially prohibiting future orders in the event of non-compliance or, alternatively, providing financial assistance when needed for remediation efforts, are particularly crucial. Indeed, these clauses are key to (better) aligning the implementation of labour standards with supply chain practices, just as higher prices or other means of paying for improved conditions are crucial to stopping or at least mitigating the downward pressure suppliers face in today's buyer-driven garment supply chains. While a potential withdrawal of orders can be a powerful motivator for suppliers, it is also important to ensure adequate monitoring of lead firms' commitments. Providing suppliers with the ability to raise complaints in the event that signatory companies do not perform in a way that prevents fear of commercial retaliation could provide a powerful balance.

If used as a model for future agreements, the Bangladesh Accord's enforcement mechanism could benefit from further streamlining. For instance, future arbitration clauses could combine due process with rapid timelines to avoid excessive litigiousness, promote transparency, alleviate burdensome costs, and provide final and 
binding enforcement. ${ }^{82}$ In addition to enhanced arbitration clauses, one might also consider expanding the external environment that can support such agreements. Where the Bangladesh Accord arbitrations were previously administered by the Permanent Court of Arbitration in The Hague, an alternative option would be to build a dedicated entity with a roster of arbitrators specialised in these types of agreements, and with standard procedural rules that would not only ensure such rules do not need to be established ad hoc, but that could also provide some procedural coherence and predictability between agreements.

At the same time, it is important to stress that these agreements are not exclusively conflictual in nature. Although arising out of (transnational) conflicts, they also aim to bridge them. More generally, lead firms, suppliers, and workers can potentially gain from taking a robust, practical and rule-based approach to preventing or mitigating specific labour rights risks in textile supply chains. An enforceable agreement with wide participation like the Bangladesh Accord or the Indonesia FoA Protocol encourages competition based on factors other than labour costs. Of course, such agreements also entail a risk of conflicts being created between actors who are party to the agreement and those who are not. While the Sindh government was not a party to the Ali Enterprises Arrangement itself, it agreed to play a central implementing role. The Bangladesh Accord, in contrast, operated in a far more hostile environment in which the government and employer association eventually forced the transfer of the successor agreement's operations into a national entity where the government and employers now enjoy a seat at the table.

Moving forward, it is important to highlight that we have not seen a proliferation of Bangladesh Accord-like instruments or other types of enforceable brand agreements, with the notable exception of an agreement in Lesotho combatting sexual harassment in the workplace. ${ }^{83}$ Establishing more of such agreements, as well as further developing them, monitoring them, enforcing them, and managing relations with governments, will require significant resources and coordination of labour organisations across various continents. Any agreement with far-reaching implications on purchasing practices will therefore require a significant amount of sustainable and coordinated pressure to establish it with a decent number of lead firm participants, sufficient depth in terms of company obligations, and robust legal enforceability.

How far can enforceable agreements really go in terms of radically altering purchasing practices and fully aligning them with human rights concerns? On the one hand, they have done far more than other private initiatives to date. On the other hand, however, one can also legitimately argue that they have only managed to partially address the sourcing squeeze at the root of many of the violations in the

\footnotetext{
${ }^{82}$ One such option is offered by the "Model Arbitration Clauses for the Resolution of Disputes under Enforceable Brand Agreements." Clean Clothes Campaign et al. (2020).

${ }^{83}$ Worker Rights Consortium, Landmark Agreements to Combat Gender-based Violence and Harassment in Lesotho's Garment Industry, www.workersrights.org/commentary/landmarkagreements-to-combat-gender-based-violence-and-harassment-in-lesothos-garment-industry/ (last accessed 30 August 2020).
} 
globalised garment supply chains they seek to address. While all of the agreements covered in this chapter did generate specific lead firm behaviour changes that otherwise would not have materialised, and therefore can be said to (sometimes significantly) alter conditions in supply chains, it might be easier to engage lead firms in more targeted agreements that focus on gender-based violence or workplace safety. The safety renovations that were funded through Article 22 of the Bangladesh Accord and other supply chain compensation fund agreements clearly demonstrate that these agreements can force lead firms into punctuated redistributive events. Yet, to what extent enforceable agreements between worker organisations and lead firms can bring about more significant structural, economic shifts like a durable wage increase, for example, remains to be seen.

\section{References}

Anner M (2013) Workers' power in global value chains. In: Fairbrother P, Lévesque C, Hennebert M (eds) Transnational trade unionism: building union power. Taylor and Francis, New York, pp 23-41

Anner M (2018) Binding power: the sourcing squeeze, workers' rights, and building safety in Bangladesh since Rana Plaza. Center for Global Workers' Rights, Penn State University

Anner M et al (2012) Buying power, pricing practices and labor outcomes in global supply chains. Institutions Program Working Paper Series, University of Colorado

Anner M et al (2013) Toward joint liability in global supply chains: addressing the root causes of labor violations in international subcontracting networks. Comp Labor Law Policy J 35(1):1-43

Arengo E et al (2019a) Calling for remedy. International Labor Rights Forum

Arengo E et al (2019b) Future of fashion, worker-led strategies for corporate accountability in the global apparel industry. International Labor Rights Forum

Blasi J, Bair J (2019) An analysis of multiparty bargaining models for global supply chains. International Labour Organization

Connor $\mathrm{T}$ et al (2016) The freedom of association protocol: a localised non-judicial grievance mechanism for workers' rights in global supply chains. Non-Judicial Redress Mechanisms Report Series 19

Cowgill M, Huynh P (2016) Weak minimum wage compliance in Asia's garment industry. International Labour Organization

Den Hond F et al (2014) A strategic-interaction analysis of an urgent appeal system and its outcomes for garment workers. Mobil Int Q 19(1):83-112

Gardener D (2012) Workers' rights and corporate accountability - the move towards practical, worker-driven change for sportswear workers in Indonesia. Gender Dev 20(1):49-65

Gregoratti C, Miller D (2011) International framework agreements for workers' rights? Insights from River Rich Cambodia. Glob Lab J 2(2):84-105

Hensler B, Blasi J (2013) Making global corporations' labor rights commitments legally enforceable: the Bangladesh breakthrough. Workers Rights Consortium

Locke R (2013) The promise and limits of private power: promoting labor standards in a global economy. Cambridge University Press, New York

Miller D (2012) Last nightshift in Savar: the story of the Spectrum Sweater factory collapse. McNidder \& Grace, Alnwick

Reinecke J, Donaghey J (2015) After Rana Plaza: building coalitional power for labour rights between unions and (consumption-based) social movement organisations. Organization 22 (5):720-740

Terwindt C et al (2017) Supply chain liability: pushing the boundaries of the common law? J Eur Tort Law 8(3):261-296 
Ben Vanpeperstraete studied sociology and anthropology at the Université Libre de Bruxelles (Free University of Brussels), Belgium. He has worked on the intersection between labour rights, human rights due diligence and international trade, with a focus on the clothing sector. He has supported global unions' work on the legally binding Accord on Fire and Building Safety in Bangladesh and contributed to the Rana Plaza, Tazreen and Ali Enterprises compensation arrangements. Vanpeperstraete has furthermore worked on EU trade policy, especially on the EU Bangladesh Sustainability Compact and the Everything but Arms Cambodia investigation. In spring 2020, he joined ECCHR's Business and Human Rights programme as a senior legal advisor.

Open Access This chapter is licensed under the terms of the Creative Commons Attribution 4.0 International License (http://creativecommons.org/licenses/by/4.0/), which permits use, sharing, adaptation, distribution and reproduction in any medium or format, as long as you give appropriate credit to the original author(s) and the source, provide a link to the Creative Commons license and indicate if changes were made.

The images or other third party material in this chapter are included in the chapter's Creative Commons license, unless indicated otherwise in a credit line to the material. If material is not included in the chapter's Creative Commons license and your intended use is not permitted by statutory regulation or exceeds the permitted use, you will need to obtain permission directly from the copyright holder.

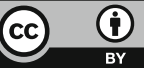

